\title{
Os enigmas da Vulgata: Colombo hermeneuta
}

Alfredo Cordiviola ${ }^{a}$

\begin{abstract}
Resumo
Este trabalho analisa o legado de Cristovão Colombo como navegante que altera definitivamente as percepções do mundo, mas também como hermeneuta que percorre a Vulgata para indagar os planos divinos e o lugar que a ele próprio corresponderia desempenhar diante dos singulares acontecimentos decorrentes da aparição das Índias na episteme da época. Perfazendo suas leituras da Bíblia e os métodos que guiam sua exegese, examinamos alguns dos seus escritos, tais como as cartas, as relações e o chamado Libro de las profecías, e descrevemos em particular as atribuições dadas pelo Almirante a topônimos e lugares como Ofir ou o Paraíso, que, segundo suas interpretações, poderiam confirmar a condição de uma geografia sacra que, prenunciada pelos profetas e autoridades, já postulava a existência do continente americano.
\end{abstract}

Palavras-chave: Colombo, hermenêutica, Ofir.

${ }^{\text {a }}$ Professor titular do Departamento de Letras da UFPE e coordenador do Grupo de Pesquisa do CNPq Literatura hispano-americana colonial, alfredo.cordiviola@gmail.com. 
Das primeiras cartas e do Diário de navegação de 1492 em diante, os textos colombinos confirmaram que o mundo era muito mais vasto e mais complexo do que se imaginara. Revelando as gentes, os lugares e as peripécias que marcaram as travessias atlânticas do Almirante, também confirmaram, por outra parte, que Colombo não pretendia ser apenas um navegante que se limitasse a descrever percursos e a compor sumárias narrativas de viagem, mas que, antes de tudo, assumia ser o intérprete - e o protagonista - de um plano divino que tinha amplificado quase ao infinito as fronteiras do orbe.

Colombo deve se apresentar como intérprete sagaz uma e outra vez; intérprete que sabe decifrar os avisos, tanto os mais evidentes quanto os mais herméticos, que podem ser igualmente descobertos na ímpar geografia das Índias ou nas sempre verdadeiras enunciações bíblicas. Deve também se exibir como protagonista absoluto, singularmente escolhido para levar a todos os confins a palavra de Cristo, para ser o Christo ferens capaz de completar definitivamente a missão de expansão universal do Verbo dada aos apóstolos. Para o Almirante, portanto, parece evidente que relatar as maravilhas que surgiam em cada itinerário teria sido uma tarefa menor e incompleta, se não se indagavam os sentidos últimos que justificavam e davam um norte certeiro a tais deslocamentos. Não bastava ser o navegante que vê e nomeia novas realidades nem o adelantado que outorga novas possessões e riquezas à Coroa, mesmo que essas intervenções viessem a mudar definitivamente a ordem do mundo. Era preciso também se submeter ao escrutínio das interpretações que permitissem entender o que estava acontecendo e o que haveria de acontecer.

Os escritos do Almirante tornam públicas várias das suas faces: o navegante que desbrava os mares, o estrategista destemido que funda cidades para garantir uma melhor exploração do território conquistado, o investidor que anuncia extraordinárias riquezas vistas ou imaginadas, o vassalo humilde ao serviço da Coroa, o visionário que garante os caminhos da evangelização futura, o apologista de si que multiplica hipérboles para se promover, o político que disputa seus direitos e suas posições entre as intrigas que imperam no reino. Todas essas facetas servem como complemento ao nome próprio que as unifica, mas em definitivo acabam sendo assimiladas por uma figura ainda mais ampla, que as legitima 
e lhes confere um valor final. Essa figura, que Colombo alimentou cuidadosamente ao longo de toda sua trajetória, é a figura do hermeneuta.

Esse papel de hermeneuta, que Colombo não deixa de desempenhar em suas cartas e memoriais, em nenhum texto se evidencia tanto quanto no chamado Livro das Profecias. Escrito provavelmente entre 1502 e 1504, em colaboração com frei Gaspar de Gorricio, o manuscrito reúne numerosas citações bíblicas, trechos de autores como Isidoro de Sevilha, Santo Tomás, Santo Agostinho, Nicolás de Lyra ou Pierre d’Ailly, entre outros. Há também, a modo de implícito prefácio, duas breves cartas intercambiadas por Colombo e Gorricio e, já no corpo do texto, uma terceira, mais longa, escrita por Colombo em 1501 aos Reis Católicos, nas quais se manifestam os propósitos que sustentam a obra.

O Livro se constrói a partir da elisão de uma voz que salvo nas cartas mencionadas - prefere não se manifestar, mas que está presente em todas as páginas. Não há prólogos, nem introduções, nem apresentações que explicitem o grão dessa voz que, contudo, é onipresente, porque separa e transcreve cada recorte, cada escolha e cada ordenamento das frases e dos nomes que conformam o manuscrito. Florilégio de citações colocadas para dialogar entre si e por si mesmas como ilhas solitárias em um arquipélago de revelações, o texto dispensa toda explicação e se limita a reunir e enunciar, de forma ainda mais clara e eficaz, tudo aquilo que - antes esparso na Bíblia e nas páginas dos autores citados - viesse a sustentar os argumentos do Almirante. Desta forma, os fragmentos estão dispostos para emitir uma luz própria e evidente, como se fossem epígrafes de uma obra que já tinha sido escrita antes pelos profetas e pelas autoridades que anunciaram os destinos da humanidade.

A singular crestomatia fornece assim um catálogo de referências e autoridades que versam sobre os passados, o presente e os futuros de mundo vistos a partir da ótica do Almirante e sob a luz da existência das antes ignotas terras de ultramar. No Antigo Testamento e nos Evangelhos, no Gênese e no Apocalipse, nos anúncios de Isaías e de Ezequiel, de Daniel e de Jeremias, nas inquisições de Agostinho e de Tomás, Colombo encontra isso que todos os cristãos contemporâneos seus achavam nessas páginas: verdades. Não surpreende que Colombo procurasse desvendar as 
interrogações que o destino lhe deparara nas páginas das Escrituras; elas ensinavam a história das civilizações, os tempos da criação e do devir, os modos da Providência, o horizonte inexorável das últimas coisas. Aquilo que aconteceu e aquilo que aconteceria estava tudo escrito, mesmo que, às vezes, o sentido parecesse velado, e as respostas obscuras ou incertas. É por isso que tinha de haver intérpretes, capazes de revelar enigmas e de atualizar os veneráveis enunciados a partir dos novos eventos ocorridos no mundo.

Mas Colombo não era teólogo, e sabia que não estava autorizado a formular comentários que eventualmente poderiam ser considerados inadequados ou heréticos. Laico, sem formação específica nem estrutura eclesiástica em que se apoiar, a única maneira possível de validar seu papel de hermeneuta consistia em invocar os efeitos da determinação divina, que, conforme tudo parecia indicar, tinha decidido guiá-lo nessa tarefa. Para que Colombo se erija como o exegeta das verdades, como aquele que duplamente vem a revelar - na geografia e na Palavra - o que estava oculto nos horizontes do sentido, deve então exaltar sua ignorância, nunca reivindicar sua sabedoria; deve enfatizar sua inocência, nunca sua argúcia; deve se reconhecer como humilde pecador, nunca como ambicioso comandante. São esses os recursos que utiliza na mencionada carta escrita aos Reis Católicos, inclusa no Livro das profecias.

A carta se inaugura com uma hipótese que pretenderá ser comprovada no decorrer dos seus sentenciosos parágrafos: “La razón que tengo de la restituiçion de la Casa Santa a la Santa Iglesia militante es la siguiente", escreve o enfático Colombo, anunciando a teoria que haverá de defender até sua morte em vários escritos, e que conforma o foco principal das suas argumentações. Essa teoria que Colombo imagina postula que todo o ouro das Índias haverá de servir para um magno propósito: recuperar a Terra Santa para a cristandade. Se a evangelização dos indígenas foi tantas vezes postulada (por Colombo, por Las Casas e tantos outros) como a justificativa primordial da empresa colonizadora, vincular essa empresa com a recuperação de Jerusalém, como pretende o Almirante, outorga às explorações marítimas e à posse e usufruto das riquezas das Índias uma missão providencial ainda mais contundente, subordinando desse modo a exploração das 
benesses de ultramar a um fim último que excede (e autoriza) toda ambição pessoal e toda expansão imperial.

Trata-se, não há dúvida, de uma teoria ousada ou quiçá inviável, que Colombo enuncia como homem de ação e como hermeneuta, e que, segundo ele, estaria fundamentada nas visões dos profetas maiores e nos diversos versículos coletados das Escrituras que compõem o Livro. Comprovar essa teoria é a intenção capital dessa obra, que, posteriormente conhecida como Livro das profecias, Colombo no entanto decididamente intitula "Libro o gavilla de autoridades, dichos, sentencias y profecías acerca del asunto de la recuperación de la Ciudad Santa y del monte de Dios de Sión, y del descubrimiento y la conversión de las islas de la India y de todas las gentes y naciones". A carta aos Reis Católicos é assim o espelho onde se revela, em toda sua nitidez e densidade, a potência performativa desse título.

$\mathrm{Na}$ carta, depois de se apresentar como navegante experiente, o Almirante relembra os anos passados desde aquele momento decisivo em que "me abrió Nuestro Señor el entendimiento con mano palpable a que era hacedero navegar de aqui a las Indias y me abrió la voluntad para la hexecuçión d'ello". Esse é o momento mais determinante da sua história pessoal, mas, longe de se reduzir a um mero episódio subjetivo, esse momento indica também a concretização mais plena dos desígnios superiores e a fundação mesma do grandioso poder terreno que seria encarregado de cumpri-los. Situado nas encruzilhadas, e no epicentro, do poder celestial e do poder terrestre, Colombo não pode se limitar somente a promulgar hipóteses, e está obrigado também a convalidar seus dotes interpretativos. Seu projeto não consiste apenas em afirmar verdades, mas também em atestar suas faculdades para poder enunciar tais verdades. É por isso que, em outros parágrafos da carta, se resguarda de possíveis objeções e cautelosamente escreve:

Pudiera ser que Vuestras Altezas y todos los otros que me conosçen, y a quien esta escritura fuera amostrada, que en secreto o públicamente me reprehenderán de reprehensión de diversas maneras: de non doto en letras, de lego marinero, de hombre mundanal, etc. Respondo aquello que dixo San Mateus: "O Señor, que quisestes tener secreto tantas cosas a los sabios y rebelástelas a los inocentes". Y el mismo San 
Mateos: "Yendo Nuestro Señor en Jherusalem, cantaban los mochachos: 'Osana hijo de David'. Los escribas, por le tentar, le preguntaron si oia lo que desían, y él les respondió que si disiendo "¿No sabéis vos que de la boca de los niños e inocentes se pronunsçia la verdad?” (COLÓN, 1992, p.13).

Baseado no apóstolo, Colombo invoca sua inocência e sua ignorância não como obstáculos, mas como garantias de que um "non doto, lego marinero, hombre mudanal" seria preferido para servir de canal das revelações. É um tópico que também está presente nas Trovas de Bandarra que, um século e meio depois, dariam a Antonio Vieira instrumentos para escrever sua História do Futuro. Como o humilde sapateiro de Trancoso, Colombo diz ser uma alma simples que fora agraciada para mostrar ao mundo as verdades ocultas. Eleito pela Providência para atravessar os mares e descortinar novos mundos, deve completar agora sua missão, mostrando nas Escrituras as causas e as consequências dos seus iluminados itinerários.

Colombo sabe que os labirintos da interpretação podem ser mais esquivos, e mais perigosos, que as águas do mar Atlântico. Como afirma na carta,

Los profetas, escriviendo, fablavan de diversas maneras: el de porvenir por pasado y el pasado por porvenir, y asimismo del presente; y disieron muchas cosas por semejança, otras propincas a la verdad y otras por entero a la letra; y uno más que otro, y uno por mejor manera, y otro no tanto (COLÓN, 1992, p.14).

Mas sabe também que, sem a interpretação que a valide, a sua portentosa descoberta seria apenas um capítulo na história da expansão marítima. Seja "por semejança" ou "por entero a la letra", de forma literal ou alegórica, sua chegada nas Índias devia de alguma forma estar vaticinada nas Escrituras. Se as "diversas maneiras" das falas dos profetas já tinham noticiado as futuras viagens colombinas, as viagens colombinas agora vinham a esclarecer as enigmáticas revelações dos profetas. Nesse círculo que encerra os milênios, nessa circunferência na qual a vidência e a anunciação se encontram definitivamente com a explicação e o fato consumado, tudo parece levar a um destino final que vem a sustentar os raciocínios e as interpretações do navegante. Como continua a carta aos Reis, "Nuestro Redentor diso que antes de la consumación 
d'este mundo se abra de conplir todo lo quéestava escrito por los Profetas". Ou seja, se as profecias estão sendo cumpridas, se as Índias se manifestaram no horizonte como a condição necessária para a iminente restituição da Casa Santa, e se toda a verdadeira história da humanidade estava na Bíblia, o corolário obrigado dessas premissas só podia ser um: a consumação dessa história e deste mundo estava próxima. Amparado por Santo Agostinho ("que diz que la fin d'este mundo ha de ser en el sétimo millenar de los años de la criación d'el"), Colombo se atreve assim a calcular o tempo que resta:

De la criaçión del mundo o de Audán fasta el avenimiento de Nuestro Señor Jhesu Christo son cinco mil e tresientos y cuarenta y tres años y tresientos y diez e ocho días por la cuenta del rey don Alonso, la cual se tiene por la más çierta. Pedro de Ayliaco, Elucidario astronomice concordie cum theologica et hystorica veritate, sobre el verbo $X$, con los cuales poniendo mil y quingentos y uno inperfeto, son por todos seis mil ochoçientos cuarenta y cinco imperfetos. Segund esta cuenta, no falta salvo çiento e cincuenta y cinco años para complimento de siete mil, en los cuales dice ariba por las abtoridades dichas que avrá de feneçer el mundo (COLÓN, 1992, p.14).

Somente cento e cinquenta e cinco anos era o que faltava para que as previsões do Apocalipse finalmente se cumprissem. Essa era a dedução de Colombo, e a conclusão última de todas suas interpretações. A sua chegada às Índias podia ser indício certo da grandeza espanhola, da salvação dos indígenas, da recuperação dos sagrados lugares, mas se esses indícios eram corretos, os capítulos seguintes corresponderiam ao Anticristo, ao reinado milenar e aos últimos dias. Isso estava na Bíblia, isso é o que o Almirante lê quando lê a si mesmo. Se esses indícios eram corretos, então a "inpresa de las Indias" representava o momento determinante nas eras previstas pela escatologia. A chegada às Índias preparava o caminho para a conflagração final e acelerava o desenlace da história. Nesse drama, Colombo havia cumprido já e continuava cumprindo (ao escrever textos como a carta aos Reis e o Livro) um papel central: como navegante, imaginava ser o portador de Cristo; como intérprete, o arauto do fim dos tempos.

Situada nos primeiros fólios do Livro das profecias, desta forma a carta aos Reis adquire toda sua dimensão no contexto 
da obra. Se parece destoar no meio de tantas citações alheias, se, de forma intempestiva, introduz a figura de uma primeira pessoa e uma marca autobiográfica que, como dissemos, permanecem ausentes em toda a obra, por outro lado essa carta é absolutamente crucial na sua função de dar um propósito definitivo ao Livro. A carta transforma um heterogêneo arrazoado de fragmentos em um documento de constâncias e de provas. É um centro de gravidade, que com sua atração centrípeta instaura um ordenamento lógico entre as citações, que se remetem à carta para evidenciar sua pertinência e adequação dentro do marco estabelecido pelo manuscrito. A carta, escrita antes da última viagem do Almirante, não apenas pretende reforçar os argumentos defendidos por Colombo, mas também, como vimos, cumpre o fundamental objetivo de legitimar seu modo de ler a Vulgata, de autenticar sua capacidade como intérprete idôneo, três vezes idôneo: porque viajou, porque entendeu o que viu graças aos prismas da Escritura e, antes de tudo, porque foi agraciado por Deus para viajar e para entender. Se as viagens tinham aberto as portas das maravilhas, é somente nas Escrituras - e não na cartografia nem no território das Índias - onde finalmente todos os percursos podem ser decodificados, mediante a suprema instância da vontade divina.

Nesse sentido, no marco da radical reconfiguração da episteme que define o final do século XV europeu e que impulsiona a revolução na cartografia inaugurada pelo mapa de Juan de La Cosa, o Livro das profecias é o resultado mais patente das leituras, anotações e interpretações de Colombo, do Colombo leitor que percorre a Vulgata em busca de explicações e de certezas que permitam entender e justificar tais notórios acontecimentos. Certamente não é a única evidência dessas leituras e dessas buscas, já que Colombo exibe suas chaves hermenêuticas e defende a cara hipótese da futura restauração de Jerusalém também em outros textos, mas o Livro oferece a argumentação mais completa e a que tenciona ser a mais fundamentada desse programa exegético.

Nesse programa, a visão escatológica, os anúncios da Parúsia, as invocações aos profetas, as elucubrações emanadas da alegoria poderiam ser instrumentos previsíveis e obrigatórios, porque já estavam instalados firmemente na tradição exegética. Como afirma Juan Luis de León Azcárate, 
La exégesis colombina es en gran medida deudora de la exégesis medieval. De ella toma, fundamentalmente: a) la interpretación alegórica o tipológica de la Escritura, y b) la visión providencialista por la que todos los eventos de la Humanidad están comprendidos y vaticinados en la Escritura. Colón, por tanto, no crea un nuevo modelo de interpretación. Simplemente recoge, ayudado por fray Gaspar de Gorricio, los elementos que más le convienen de la exégesis bíblica de su tiempo con el fin de interpretar el descubrimiento de las Indias como un evento preconizado en la Escritura (AZCÁRATE, 2007, p. 400).

Colombo, contudo, dista de ser apenas mais um leitor das Escrituras, atribulado, como tantos outros, pelo presente e pelo futuro. Como dissemos, aquilo que o diferencia de outros intérpretes é aquilo que está inscrito no seu destino: as Índias. Desta forma, através do cristal que as Índias, as viagens e as experiências impõem diante dos seus olhos, lê as profecias de Isaías, instituindo-o (como também faria profusamente Antonio Vieira) como o visionário que tinha prenunciado a existência das terras de ultramar e urgira a incorporá-las ao orbe cristão. Desta forma, lê o insigne papel que lhe tocava cumprir, enquanto portador e intérprete, na história da humanidade. Desta forma, enfim, insiste em ler a geografia das Índias não somente como tesouro de plenitudes, abundante em ouro, em verdes intensos e em almas singelas e tementes, mas também como superfície de reconhecimento e de revelação de topônimos que transitam pela geografia da Vulgata.

Este será seu exercício constante, mediante o qual, através da invocação do topônimo, o presente das navegações e os passados inscritos na Bíblia se transformam em caras da mesma moeda. Esse exercício, contudo, não se restringe a indicar meras semelhanças, concordâncias ou equivalências. A tarefa é muito mais ambiciosa, pois aponta a desvendar, identificar e corroborar os vínculos entre o topônimo bíblico e um lugar específico que vislumbra nas Índias, ou também entre um topônimo bíblico e o conjunto das terras transatlânticas. Um exemplo da primeira forma de identificação reside nas evocações que Colombo faz do Paraíso; um exemplo da segunda se encontra nos usos e aplicações de Ofir.

São muito conhecidas suas alusões ao Paraíso Terreal, enunciadas de forma indireta (ao enfatizar a benignidade do clima, as virtudes da natureza e as bondades das suas criaturas) 
ou direta, quando se refere a algum ponto particular do continente. Nos compêndios de Las Casas e nas próprias cartas e memoriais do Almirante é recorrente a menção ao Paraíso, partindo já das referências a esse "lugar temperadísimo" que aparecem no Diário da sua primeira viagem, na entrada da quinta-feira, 21 de fevereiro. Retornando das Índias, enquanto navegava entre as ilhas de Santa Maria e São Miguel, e quando ainda faltavam dez dias para sua chegada a Portugal, Las Casas escreve que

Concluyendo, dice el Almirante que bien dijeron los sacros teólogos y los sabios filósofos que el Paraíso Terrenal está en el fin de Oriente, porque es lugar temperadísimo. Así que aquellas tierras que ahora él había descubierto es -dice él- el fin del Oriente (COLÓN, 1997, p. 148).

Esta enunciação em terceira pessoa seria muitas vezes ratificada pela própria voz de Colombo em várias outras passagens, notadamente na "Carta del Almirante a los Reyes Católicos", escrita para narrar sua terceira viagem e datada em 3 de agosto de 1498. Nessa carta, Colombo elabora sua célebre disquisição acerca das formas do mundo e da localização do Paraíso. Depois de referir os debates que na tradição tinham tentado confirmar essa localização (que apontavam para lugares tão distantes entre si como a Etiópia, o Oriente ou as ilhas Canárias), o Almirante vê na por ele chamada Boca del Dragón indícios certos do Paraíso Terreal. Ali, no golfo de Pária, entre a ilha de Trinidad e a terra firme, Colombo acredita ser possível assinalar esse lugar "adonde no puede llegar nadie, salvo por voluntad divina". Para a teologia medieval, o Paraíso estaria situado nos limites orientais da Ásia, provavelmente no cume de alguma montanha, já que nunca poderia ter sido atingido pelo Dilúvio. Colombo concorda com a localização oriental, mas não com a teoria da montanha; movido por uma imaginação rara, sugere que o mundo devia ter a forma de uma pera, em cujo "mamilo" estaria o Paraíso. Esse mamilo estaria então precisamente lá, na foz do grande rio que depois seria chamado Orinoco:

Yo no tomo que el Paraíso Terrenal sea en forma de montaña áspera como el escrebir de ellos nos amuestra, salvo que él sea en el colmo allí donde dije la figura del pezón de la pera 
y que poco a poco, andando hacia allí, desde muy lejos se va subiendo a él; y creo que nadie no podría llegar al colmo como yo dije, y creo que pueda salir de allí esa agua, bien que sea lejos y venga a parar allí donde yo vengo y faga este lago. Grandes indicios son éstos del Paraíso Terrenal, porque el sitio es conforme a la opinión de estos santos e sanos teólogos, y asimismo las señales son muy conformes, que yo jamás leí no oí que tanta cantidad de agua dulce fuese así dentro e vecina con la salada; y en ello ayuda asimismo la suavísima temperancia. Y si de allí del Paraíso no sale, parece aún mayor maravilla, porque no creo que se sepa en el mundo de río tan grande y tan fondo (COLÓN, 1997, p. 384).

Invocando autoridades que seriam grandes protagonistas do Livro das profecias (Pierre d'Ailly, Esdras, São João, Santo Agostinho, entre outros), insiste em ver nesse rio que "procede de tierra infinita" o lugar onde a humanidade tinha sido feliz um dia:

Torno a mi propósito de la tierra de Gracia y río y lago que allí fallé, atán grande que más se le puede llamar mar que lago, porque lago es lugar de agua, y en seyendo grandes se dice mar, como se dijo a la mar de Galilea y al mar Muerto, y digo que si no procede del Paraíso Terrenal que viene este río y procede de tierra infinita, pues el Austro, de la cual fasta agora no se ha habido noticia, mas yo muy asentado tengo en el ánima que allí adonde dije es el Paraíso Terrenal y descanso sobre razones y autoridades sobrescriptas (COLÓN, 1997, p. 392).

Em outra das suas cartas, escrita para o Papa Alexandre VI em fevereiro de 1502 (o mesmo ano em que começaria com frei Gorricio a anotar o Livro das profecias), Colombo volta a mencionar o assunto. Resumindo as três viagens realizadas até esse momento, e os frutos dessas viagens ("Descubrí deste camino y gané 1400 islas y 333 leguas de la Tierra Firme de Asia, sin otras islas famosísimas, grandes y muchas al oriente de la isla Española, en la cual yo hice asiento"), volta a incorrer na tentativa de edificar uma geografia mística nas terras ressurgidas no horizonte. Para legitimar seus eventuais achados, mais uma vez se insere na linhagem dos sábios e iluminados, que tinham entrevisto a verdade que ele próprio viria agora a confirmar: yo hallé tierras infinitísimas y el agua de la mar dulce. Creí y creo aquello que creyeron y creen tantos santos y sacros teólogos, que allí en la comarca es el Paraíso Terrenal (COLÓN, 1997, p. 479). 
É notável como nessa mesma carta haverá de se referir à ilha Española, que nessa época continuava sendo o principal domínio espanhol nas Índias. Além de recorrer às hipérboles que eram a regra desde os relatos da primeira viagem, Colombo não duvida em adscrever ao enclave todo tipo de atributos bíblicos e fantásticos:

En ella hay mineros de todos metales, en especial de oro y cobre: hay brasil, sándalos, linoáloes y otras muchas especias, y hay incienso; el árbol de donde él sale es de mirabolanos. Esta isla es Tarsis, es Cethia, es Ophir y Ophaz y Çipanga, y nos le habemos llamado Española (COLÓN, 1997, p. 479).

Todos estes lugares estariam situados no Oriente. Salvo Cipango (que reverbera na imaginação ocidental a partir das viagens de Marco Polo), todos tinham sido descritos em diversas fontes do Antigo Testamento, como O Livro dos Reis, Isaías, Jeremias ou as Crônicas. Todos se referiam a terras distantes, com as quais em tempos remotos se mantinha um intenso tráfico de navios mercantes, que de lá traziam ouro, prata, marfim, e animais exóticos, como macacos e pavões. Todos esses lugares, apesar de que, segundo a tradição, estavam situados em pontos muito distantes entre si (Cipango no Extremo Oriente, Ofir na Índia, Tarsis na Península Ibérica), eram, para Colombo, apenas um e o mesmo. Todos se referiam à ilha Española, ou também, a esse vasto território que se estendia da Española rumo ao ocidente e ao sul, e que ainda faltava desvendar.

A centralidade do ouro, que seria a principal riqueza destas comarcas, provaria ser um argumento capital para sustentar as hipóteses do Almirante. Se ouro era necessário para reconquistar Jerusalém e promover o triunfo universal do cristianismo, o ouro estava lá, continuava estando onde as Escrituras indicaram. Se Tarsis e Ofir tinham sido achados, era justamente para tornar possível essa empresa. De Ofir viera o ouro que Salomão precisava para construir seu Templo, de Ofir viria agora mais ouro para edificar a Casa Santa. Como Hiram, o rei de Tiro que, com Salomão, dominava os mares e as rotas comerciais da antiguidade, Colombo imaginava ser o navegante que, restituindo os itinerários daquelas rotas, restituía a possibilidade de voltar definitivamente a Sião. Como afirma James Romm, 
As a new Hiram, voyaging once again to Ophir and supplying the wealth needed to rebuild the ancient temple, Columbus saw himself taking part in a grand reenactment of a glorious moment in the biblical past; and such return to early mythic patterns confirmed his belief that the ancient prophecies were being fulfilled and that history was at last reaching its end (ROMM, 2001, p.33).

As menções a Tarsis e Ofir ocupam, como não podia ser de outra forma, várias páginas do Livro das profecias. Citações do Gênese, do Paralipomenon, dos Reis e dos Salmos entre outros apontam a confirmar a hipótese de Colombo, que defende insistentemente a condição insular de Tarsis. As fontes indicavam que "Tarsis" podia significar várias coisas (uma ilha, um nome próprio, uma cidade da Cilícia, uma região da Índia, um mar, um tipo de pedra), mas Colombo, que recolhe todas estas versões, optará por preferir a mais conveniente para sua argumentação. Ofir também é apresentado como ilha, mas antes de tudo como o reservatório do ouro, de todos os talentos de ouro utilizados por Salomão na sua magna obra. O Livro recolhe também referências feitas por Jeremias e Isaias a outra ilha, chamada Quetim, que para Colombo se trata de mais um nome dado para a mesma entidade. O Almirante não duvida que Tarsis, Ofir e Quetim, variações de um mesmo topônimo, aludem a uma ilha no mar; com as citações que reforçam esta teoria conclui o Livro.

Esses dois elementos -a condição insular, a abundância de ouro-formam, como sabemos, o fundamento da argumentação colombina, que o Almirante volta a aprofundar em outra carta posterior, conhecida como "Lettera rarissima”, escrita aos Reis, por ocasião da sua quarta e última viagem, em Jamaica no dia 7 de julho de 1503. A carta inclui uma firme apologia do ouro como instrumento de redenção ("El oro es excelentísmo; del oro se hace tesoro, y con él, quien lo tiene, hace cuanto quiere en el mundo, y llega a que echa las ánimas al Paraíso"), uma nova materialização de Ofir, neste caso em Veragua, e uma exortação ou convite aos Reis para que se apropriem das riquezas existentes:

A Salomón llevaron de un camino seiscientos sesenta y seis quintales de oro, allende los que llevaron los mercaderes y marineros, y allende lo que se pagó en Arabia. De este oro fizo doscientas lanzas y trescientos escudos, e fizo el tablado 
que había de estar arriba, pellas de oro y vasos muchos y muy grandes y ricos de piedras preciosas. Josefo, en su crónica De antiquitatibus, lo escribe. En el Paralipomenon y en el Libro de los Reyes se cuenta de esto. Josefo quiere que este oro se hobiese en la Aurea. Si así fuese, digo que aquellas minas de la Aurea son unas y se contienen con estas de Veragua, que, como yo dije arriba, se alargan al poniente veinte jornadas y son en una distancia lejos del polo y de la línea. Salomón compró todo aquello, oro, piedras y plata, y V.A. le pueden mandar a coger si les place. David, en su testamento, dejó tres mil quintales de oro de las Indias a Salomón para ayudar a edificar el templo, y según Josefo, era él de estas mismas tierras. Hierusalén y el monte Sión ha de ser reedificado por manos de cristianos (VARELA, 2000, p. 289).

Muito ouro, de fato, transportariam as novas expedições salomônicas ao longo do século XVI. Mas Sião jamais seria recuperada, nem o Templo reedificado. Não haveria nenhum outro Flávio Josefo para narrar essa outra saga de navegantes que atravessavam o mundo para retornar, salvos e opulentos, à Casa Santa que Colombo vislumbrava.

De fato, nem tudo aconteceu como o Almirante pensara, nem como as Escrituras pareciam ter avisado, nem como uma misteriosa voz tinha afirmado, aquela voz que aparece no famoso episódio narrado nessa mesma carta de Jamaica de 1503. Colombo escreve que, estando muito febril, doente, adormecido, escuta "uma voz muy piadosa" que lhe garante ter sido o escolhido. "Deus", afirma a voz, "hizo sonar tu nombre en la tierra. Las Indias, que son parte del mundo tan ricas, te las dio por tuyas". Antes de desaparecer, a voz consola o Almirante, e diz: "No temas, confía; todas estas tribulaciones están escritas en piedra mármol y no sin causa". Sem temer jamais os anacronismos, nem as hipérboles, nem os efeitos da multiplicação das fantasias cosmográficas, nem as contradições e paradoxos que tinham balizado suas interpretações, Colombo dedicou toda sua trajetória a assumir esse papel de hermeneuta mor e de navegante inspirado que a voz vinha (outra vez) a confirmar.

Como navegante, é evidente que, guiado por sua obstinação ou pela Trindade, conseguiu descompor para sempre os saberes históricos e geográficos constituídos e reacomodar profundamente as percepções e os contornos do mundo. Por outra parte, está claro que, como hermeneuta 
obcecado por indagar as mais profundas tramas da vontade divina, seu influxo distou de ser igualmente marcante. Mas de toda forma, não podemos esquecer que, muito depois da sua morte, ainda estava se discutindo se poderia existir alguma identidade entre o bíblico Ofir e o continente americano. $\mathrm{Na}$ esteira das interpretações inauguradas por Colombo, a controvérsia contaria ainda com muitos outros participantes e com muitos outros tratados dedicados a favorecer ou a refutar as hipóteses esboçadas nos textos do Almirante.

O povoamento da terra após o Dilúvio, o lugar do Novo Mundo e dos seus habitantes no plano universal, a origem dos indígenas, os registros ou a ausência de antigas pregações apostólicas entre eles, a eventual existência de descrições da geografia americana nas Escrituras eram todos temas que continuariam sendo ainda debatidos com intensidade ao longo dos séculos XVI e XVII. É provável que um dos maiores responsáveis pela perduração desses debates tenha sido o ilustre Benito Arias Montano. Encarregado por Felipe II de elaborar em vários idiomas a mais completa e anotada versão da Bíblia (que viria a substituir a Biblia Complutense compilada pelo cardeal Cisneros em 1520), Arias Montano edita, entre 1568 e 1572, os oito volumes da chamada Biblia Poliglota. O ambicioso projeto editorial, realizado na casa de Plantinus em Antuérpia, incluía versões em hebreu, grego, aramaico e latim, entre outros textos em siríaco e, nos três últimos volumes, um profuso aparato crítico, composto por dicionários, gramáticas, vocabulários, gravuras, mapas, cartas, tratados filológicos, arqueológicos e exegéticos.

Um desses tratados que conformam o oitavo volume é Phaleg siue de gentium sedibus primis, orbisque terrae situ. Nessa obra, Montano elabora as bases de uma geografia sacra, que pretende articular os saberes atualizados provindos da experiência com as verdades bíblicas, e os postulados da filosofia natural com os da teologia. O tratado está ilustrado por uma Orbis Tabula, um mapa do mundo que exprime os conhecimentos mais avançados da época em matéria geográfica, mas que apresenta uma topologia exclusivamente baseada nas Escrituras. Nesse mapa, anotado em hebraico, os lugares estão identificados com números e letras. O número que corresponde ao continente americano, que aparece duas vezes, assinalando as massas terrestres do sul e do norte, é o 19. Ao procurar 
a referência desse número, não há menção a nomes como América, Índias ou Mundus Novus; no seu lugar aparece uma única palavra, Ophir (ver Fig. 1).

Figura 1 - Orbis Tabula. Phaleg siue de gentium sedibus primis, orbisque terrae situ líber. Biblia Poliglota de Antuérpia, editada por Benito Arias Montano.

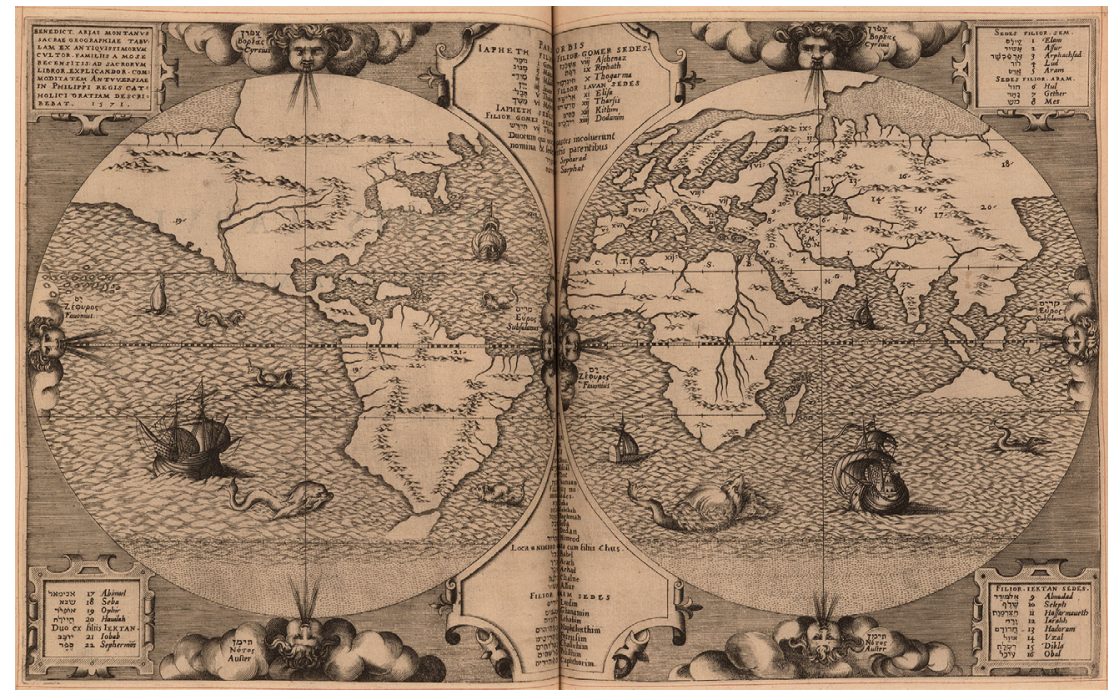

Fonte: http:/ /jcb.lunaimaging.com/luna/servlet/detail/JCBMAPS 1 1 1155 115900891:-

Orbis-tabula--Ben--Aria-Montano--A

Mediante complicados exercícios filológicos, Montano tentava comprovar, baseado (como Colombo) no Livro dos Reis e nas Crônicas, que a origem do nome "Peru" remitia a "Ophir". Peru se referia tanto ao lugar onde Salomão encontrou o ouro para seu templo (denominado "Parvaim" nas Crônicas, que Montano traduz como "duplo Peru") quanto a um dos descendentes de Noé e de Sem, cujo nome era precisamente Ophir. Com este recurso, postulava não apenas a unidade do gênero humano, mas também que os hebreus já tinham conhecido todo o mundo, e que, portanto, todo o orbe já tinha sido descrito no Testamento. Desta forma, unificando as fontes das riquezas materiais e os desígnios providenciais, concordava com o Almirante e com os autores que defendiam a identidade plena entre Ofir e as Índias em geral ou entre Ofir e o Peru em particular, como Pietro Martire (De Orbe Novo, década I), Guillaume Postel (Cosmographicae Disciplinae Compendium) ou Goropius Becanus (Origines antuerpianae). 
A legitimação dada a essa teoria por autoridade tão notória como Arias Montano assegurou a perpetuação, e as ramificações, do debate. Contudo, longe de toda unanimidade, a hipótese de Ofir teve muitos e importantes detratores, particularmente peruanos ou que conheciam muito bem o Peru, como José de Acosta, o Inca Garcilaso, o Padre Bernabé Cobo ou o jesuíta Juan de Pineda. Outros, como Fernando de Montesinos ou Gregorio García, defenderam a peregrina tese, para justificar a existência das opulentas terras de Paititi ou El Dorado ou para postular uma hipótese ainda mais curiosa, que defendia que os indígenas americanos eram descendentes das dez tribos perdidas de Israel ${ }^{1}$. Raro foi o historiador do Novo Mundo que não se ocupou do assunto, mesmo que fosse para seguir os argumentos de Acosta, que na Historia natural y moral de las Indias apresentou, como afirma José Durand, a que talvez seja a refutação mais firme das ideias que o Almirante tanto tinha defendido. Mesmo assim, se em meados do XVII o nome de Ofir ainda estava presente nas reflexões dos filósofos e historiadores das Índias, era porque a hermenêutica colombina continuava ecoando no imaginário da época. Afinal, o legado de Colombo, tão evidente na geografia física do mundo, permaneceria também em toda a literatura indiana em forma de palavras, ideias e conjecturas. Afinal, por mandato superior, por falência da aritmética, ou por implicâncias do destino, esse legado haveria de manter sua vigência por um tempo bem superior aos cento e cinquenta e cinco anos que, segundo os errôneos cálculos do Almirante, teriam restado até a consumação dos últimos dias.

${ }^{1}$ Ver Cordiviola, Alfredo. Espectros da geografia colonial. Uma topologia da ocidentalização da América. Recife: EDUFPE, 2014.

\section{REFERÊNCIAS}

COLÓN, Cristóbal. Libro de las profecías. Volumen preparado por Juan Fernández Valverde. Madrid: Alianza Editorial, 1992. COLÓN, Cristóbal. Textos y documentos completos. Edición de Consuelo Varela. Nuevas cartas. Edición de Juan Gil. 2 edición ampliada. Madrid: Alianza Universidad, 1997.

DURAND, José. "Perú y Ophir en Garcilaso Inca, el jesuita Pineda y Gregorio García”. Histórica, vol III, n 2, pp.35-55, 1979. 
DE LEÓN AZCÁRATE, Juan Luis. “El Libro de las profecías (1504) de Cristóbal Colón. La Biblia y el descubrimiento de América". Religión y Cultura, LIII, pp. 361-406, 2007.

ROMM, James. "Biblical History and the Americas: the Legend of Salomon's Ophir. 1492-1591", em Bernardini, Paolo; Fiering, Norman (eds). The Jews and the Expansion of Europe to the West. 1450 to 1800. Providence: Berghahn Books, pp. 27-46, 2001.

VARELA, Consuelo. Cristóbal Colón. Los cuatro viajes. Testamento. Madrid: Alianza Editorial, 2000.

\begin{abstract}
Vulgate's enigmas: Columbus as hermeneut

This paper analyzes the legacies of Columbus as the navigator who definitely changes the perceptions of the world, but also as the hermeneut who reads the Vulgate to inquire into the divine plans and the place that he himself would play before the singular events arising from the appearance of the Indiesin the episteme of the time. Following his understanding of the Bible, and the guidelines of his exegesis, we examine some of his writings, such as his letters, his chronicles and the work known as the Libro de las profecias, and we describe in particular the assignments given by the Almirante to toponyms and places like Ofir or Paradise, that, according to his interpretations, could confirm the condition of a sacred geography, forseen by the prophets and authorities, in which the existence of the Americas was already acknowledged.
\end{abstract}

Keywords: Columbus, hermeneutics, Ophir. 